\title{
Technology as prospective ontology
}

\section{Arie Rip}

Received: 19 April 2007 / Accepted: 18 November 2008 / Published online: 27 January 2009

C The Author(s) 2009. This article is published with open access at Springerlink.com

\begin{abstract}
Starting from common-sense notions of 'furniture of the world' a process ontology is developed in which prospective is an integral part. Technology as configurations that work (precariously) embodies expectations which structure further development. Examples (a cloned puppy, hotel keys, DC airplanes, stem cells, and overpasses on Long Island) are used to develop the notion of material narratives that are "written", not just by engineers and designers/producers, but also by users: "reading" implies some further "writing". In contrast to prevailing notions of technological control (through manipulation of building blocks), the "writing" of nanotechnology is modulation of the invisible and impredictable - an extreme example of unruly technology and repair work after the fact, where in practice control is a gesture not so different from magic. Because ontology cannot be other than prospective, it is political throughout. Thus, prospective technology highlights ontological politics.
\end{abstract}

Keywords Process ontology $\cdot$ Prospective $\cdot$ Embodied expectations · Material narrative $\cdot$ Invisible technology $\cdot$ Control $\cdot$ Modulation $\cdot$ Politics

\section{Ontology}

Engineers add to the furniture of the world, and thus shift its ontology-if we use the term "ontology" in a simplistic way (Rip 2000, p. 8). This 'adding" is not a simple, linear activity of first making something, and making it available, which is then added to the world. There is a strong prospective element. Artefacts start as technological options, a promise of functionalities, in other words 'hopeful monstrosities' (Mokyr

\footnotetext{
A. Rip $(\bowtie)$

Department of Science, Technology and Policy Studies, University of Twente, Enschede,

The Netherlands

e-mail: a.rip@utwente.nl
} 
1990; Stoelhorst 1997). This is visible, sometimes literally, in the prototypes: these embody a prospective. When they are developed further, introduced and taken up on location, they remain unfinished. Technologies are configurations that work (Rip and Kemp 1998), but always precariously. In a sense, in their practices technologies are unruly (Wynne 1988).

Scenarios, embedded in the configurations, are an integral part of their working, including the prospect of a world in which they can function optimally, at first as a "fictive script" (De Laat 1996, 2000). A key element of such a script is that the promise of a technological configuration can be realised only by changing the world so that it can accommodate the new technological options. Artificial fertilisers were effective only if the land they were applied to was reshaped so as to resemble the test plots, i.e. the circumstances under which they had been tried out. Atomic energy required a reorganisation of liabilities (insurance companies did not want to carry all of the risk) and extensive safety measures.

In general, the configurations constructed by engineers promise functionalities, but it takes time and effort to realize them (precariously). Also because the world has to adapt to their "fictive script", and need not accommodate fully. In other words, they are always prospective configurations (cf. Lente and Rip 1998 on prospective structures to be filled in by agency), and remain so because they are never finished.

Why use the term "ontology"? The notion of ontology as "furniture of the world" is not very sophisticated philosophically, but it serves to introduce the topic of my article. ${ }^{1}$ It can be read as similar to the pre-Socratic idea of the "stuff" of the world, with the additional connotation that the shapes of the "stuff" will evolve. This "stuff" of the world has a prospective element, not because there are promises and "fictive scripts" being made, but because the future is already there, prefigured in the present and evolving configuration. ${ }^{2}$

The idea of prospective ontology actually implies a general ontological point, even if I will develop it mostly in terms of technology. This general point derives from my work in actor-network theory, even if it does not depend on the details of this theory. In Callon et al. (1986) a distinction was made between existing \& evolving actornetworks, i.e. assemblages of circulating "intermediaries" which add up to actors

\footnotetext{
1 The concept of "ontology" as used in information science specifies the units or elements that will make up the software world, often with the additional requirement that these units resemble the units in the real world that is to be modelled in the software. In contrast, the notion of ontology I am using here is open-ended: it need not and cannot be fully specified, its "units" will be discovered and articulated in practices. The debate on the reduction of a chemical ontology to a physics ontology or its autonomy sits in between, because it can be limited to the epistemological status of entities like molecules, as perhaps just a specification of the kind of "software" that the discipline of chemistry will use (cf. Lombardi and Labarca 2005). Such usages of the term "ontology" are widespread. Nersessian (2006, p. 131) discusses the "ontology" of artefacts in a lab as its furniture, with devices, instruments and equipment. Van de Ven and Poole (2005) discuss alternative "ontological views of organizations as things and organizing as processes" (p. 1377), and quote Tsoukas (2005) on two versions of the social world: "one, a world made of things on which processes represent change in things; the other, a world of processes in which things are reifications of processes" (p. 1379). They do refer to a philosophical tradition of process ontologies, including Whitehead's notion of ongoing activities "prehending" what goes on in their environment (p. 1378). Later, they take this up again as "temporal predispositions" (p. 1391), similar to what I will call embedded anticipation.

2 Cf. Dupuy and Grinbaum (2006) at p. 312, about the "common but mistaken conception of the future as unreal".
} 
Fig. 1 Time-line of actor-networks $(\mathrm{AN})$ and actor-worlds (AW)

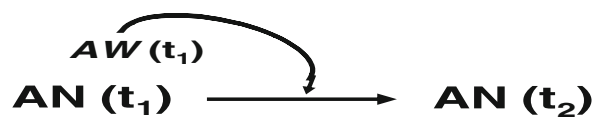

(human and non-human) but which can be decomposed again into the networks out of which they are built, and actor-worlds, the projections of future worlds, like "fictive scripts" (De Laat 1996, 2000). At any one moment, the evolving "stuff" of the world is a patchwork of actor-networks. The evolution is shaped by the actor-worlds contained in them and sometimes articulated, and the responses to them in terms of circulating "intermediaries.

At the time, we experimented with representations as in Fig. 1, a timeline of actornetworks and actor-worlds.

Such a representation can be read as how strategy and planning are commonly visualized: anticipation and then feedback into action. The point, however, is that anticipations and networks are an evolving whole, changing actor-networks are de facto enactment of overlapping and contrasting actor-worlds. Still keeping close to the strategy and governance literature, I have taken this up as "anticipation-in-action" (Rip 2006). For ontology, it implies a monistic view: the future is part of the ontology, not separate as just human projection. ${ }^{3}$ This can be brought out by emphasizing that expectations are embodied, and conversely, that the material has a narrative character (Sects. 2 and 3$)^{4}$

This is very visible in technology, and that is why a discussion of technology allows me to make the general ontological point. I shall use nanotechnology as a recurrent example, because it is not just a promising technology (up to projections of a third industrial revolution), but also requires us to re-think, and re-do, experiment and seeing-which at the nano-level is better thought of as indirect feeling (Baird et al. 2004). So it is an opportunity to consider ontology.

Having said this, I add, to avoid misunderstanding, that technology should not be limited to control and intentional assembling of building blocks. Also, when I say "prospective", I do not just think of design, as in designing an artefact or a system, which would be like the strategic planning reading of Fig. 1: design first on paper, then assemble the prototype and tinker with it (the latter would already be designin-action). I want to get away from the strong imagery of "building blocks", which is very common in mechanical engineering and is sometimes extended to technology in general. "Building the world atom by atom" is one of the slogans used for the promise

\footnotetext{
${ }^{3}$ The monism is a monism of process ontologies, e.g. Whitehead (1929) on the actual world as process, and the process is a becoming of actual entities and in another vein Bergson (1911)-on the flow of the real-, and his contemporary successor Deleuze (as Wood 2002, p. 157 phrases it). While both Whitehead and Bergson experience a revival [cf. Barry (2001, pp. 154-155), and Callon (1999)], I want to avoid their reliance on creativity, and the idea (mainly of Whitehead) that 'experience' pervades everything. Instead, I emphasize the prospective, and take technology (and landscape) as my entrance point rather than the living. In this paper, my intellectual strategy is to start (also in later sections) with commonsensical discussions of technology — and simplistic ideas of ontology — and then address further and deeper questions.

${ }^{4}$ Conversely, narratives are material, even when they are taken up as just a story. They are voiced on location, or embodied/embedded in ink on pages of text which are lay-outed, bound in a book or some other concrete package.
} 
of nanotechnology in the USA (from IWGN 1999 onward). Taken literally, it is nonsensical, but the phrase is thought to convey the message about the possibilities of the new technology to "build" whatever we want. While in fact, design is always openended, and in particular in nanotechnology, where the best one can do is to manipulate by trial-and-error and select what turns out to work, ${ }^{5}$ or to induce self-organisation of materials, e.g. of thin layers on a surface.

Complementary to the imagery of "building blocks" is the idea of control, an idea which should be deconstructed. The competence of engineers is defined as one of control, and such control is predicated on their knowledge of the building blocks of reality. ${ }^{6}$ But that knowledge is always partial, and will evolve through their interactions with the world. ${ }^{7}$ Through such interactions, however, reality is changed, intentionally and unintentionally. In other words, advance control of eventual outcomes is impossible, because the work to realize them changes the validity of the knowledge on which the ideal of control was based. In fact, repairing if things work out differently is a key component of the competence of engineers.

The limited extent of advance control is even more striking when induced selforganisation is the way to realize an artefact. Synthetic chemistry relies on partially understood self-organization, and can be seen as exemplifying another scientific/engineering tradition than physics and mechanical engineering. The two traditions are now competing in nanotechnology (Bensaude-Vincent 2006).

In the chemical tradition, the "stuff" of the world is the starting point (Stein 2004). Nordmann's reading of Heidegger can be added here: "Heidegger (1997) offers an account according to which technical control presupposes a causal picture of the world, one in which actions either poetically bring forth what lies dormant or instrumentally exploit a scheme of means-end relations." (Nordmann 2006, p. 52). My point is that "poetically bringing forth" effects is what characterizes technology, but without necessarily a determinate causal picture being involved.

A further aspect is delegation to realize effects, but not to building blocks that obey the wishes of their self-anointed master. Technology is open-ended, unruly, and in that sense out of our control. I will come back to these issues when discussing invisible technology, with nanotechnology as an extreme case (Sect. 4). And make a further, and final point about the politics of being part of a world that is being shaped without much control (Sect. 5).

\section{Embodied expectations}

The materialization of the 'not yet', as Barbara Adam has called it, ${ }^{8}$ is literally visible in prototypes like early robots which have basic functionalities but cannot do very much yet, and in demos like "the car of the future", and "the kitchen of the future"-with

\footnotetext{
5 This, by the way, is also how semiconductor manufacture started out in the $1950 \mathrm{~s}$.

6 This is a suggestive turn of phrase. Mol (1999), discussing technology and politics, notes: “... along with this it was assumed that the building blocks of reality were permanent: they could be uncovered by sound scientific investigation."

7 Compare Schön (1983)'s notion of "conversation with the situation" — where the situation will talk back.

8 In her project on sociology of the future, www.cardiff.ac.uk/socsci/futures
} 
gleaming surfaces indicating modernity/progress_-, which mobilize support for further work to materialize them. Similarly, when the US Army develops the Future Warrior it demonstrates the 'Soldier of the Future' with his 2020 Future Warrior uniform system delivering super powers, to USA Congressmen and their staff. ${ }^{9}$

Thus, the embodiment of expectations also structures further developments: mobilizing support which has demands attached to it, articulating the promise into more specific requirements for the next step. While such socio-technical "shaping" of technology does not imply a linear trajectory of increasing performance along the dimensions of functionality originally envisaged, there is structuring of the co-evolution into certain paths (and branchings) and not others.

There are also repercussions deriving from "effet d'annonce". An intriguing example is the case of Snuppy, the cloned puppy.

Researchers at Seoul National University in South Korea announced (in an article in Nature, early August 2005) that they had successfully cloned a dog. The cloned puppy was called Snuppy, and a photograph of the puppy with his father (=somatic cell donor) was featured in the scientific and professional press and the general media all over the world. The puppy looked cute, not at all a 'hopeful monstrosity'-but if one thinks of it as a technological option, that would be the right term. Snuppy was the only one of 1,095 cloned embryos implanted in 123 dogs to survive to healthy puppyhood.

Now move to the USA, the website of a firm: "Genetics Savings \& Clone enriches the lives of pet lovers through superior cloning technologies. Cat cloning available today; dog cloning available in 2005."10 Of course, you have to be assertive on your website. But when the South Koreans announced they had been successful, this implied that Genetics Savings \& Clone had to react to the implicit scenario (dog cloning will now be possible).

The Scientist (Aug 3, 2005) asked GSC for comments: "Phil Damiani, chief scientific officer of Genetic Savings \& Clone, which announced in December 2004 that it made the world's first sale of a cloned cat, said the efficiency was "probably one of the lower ones ever done for cloned animals." The company had hoped to be the first to produce a cloned dog and a few years ago had a clone that nearly came to term, Damiani told The Scientist. The fetus was alive on ultrasound, but stopped breathing by the time it was delivered by cesarean section. The Korean team has "jumped ahead," he said.

Damiani said that his company remained convinced that their technology-which relies on chromatin transfer, rather than nuclear transfer, and egg and embryo assessment prior to cloning and transfer-would eventually make it possible to clone dogs commercially.

The company expects to be able to produce a cloned dog in the next few months, said Genetic Savings \& Clone spokesperson Ben Carlson. "People have been asking us, does this mean that tomorrow you'll be able to start offering this service commercially? We wouldn't be able to make a successful business out of using the technique

\footnotetext{
9 Shown on "Soldier Modernization Day", Capitol Hill, 23 July 2004. See the pictures on www.defenselink. mil/news/Jul2004 (accessed 29 July 2005).

10 http://www.savingsandclone.com/index2.html, accessed 5 August 2005.
} 
the South Koreans used," Carlson said. The low efficiency rate, combined with stricter animal welfare rules in the United States that limit the number of times eggs can be harvested and that transfers can be made, would make it impossible. But "it certainly validates our contention that dogs can be cloned," he said. "It doesn't mean we're quite there yet."

Genetics Savings \& Clone is forced into explanations, and subsequently extra activities, because of Snuppy. This then determines further trajectories of development, and in the end, the regular existence or non-existence of cloned dogs on our planet. ${ }^{11}$ And this is not the final word. The technology and niche demands (of the "pet lovers") continue to co-evolve, and other applications might branch out.

Co-evolution is also visible in Bruno Latour's well-known analysis of hotel keys (Latour 1991). The hotel manager has to provide the guests with a key to their rooms, but wants the key back in due course. Since guests might forget to hand in their key, he puts a sign on the hotel desk: "Please hand in your key when you leave". Guests are insufficiently disciplined by the sign, so the hotel manager first puts a label on the key with the address of the hotel, so that the key can be sent back, and then makes the key heavier and unwieldy, a material incentive to get rid of the key by handing it in.

Latour is interested in what he calls the 'program' of the hotel manager and the 'counter-program' of the hotel guests who can't be bothered with returning keys. The hotel manager's wish becomes "clothed", i.e. embodied in a heavy key, so gains reality. (Latour 1991, p. 108) More interesting for our purposes is that the shape of the key is the temporary outcome of the struggle of program and counter-program. The key can stabilize the contestation, but remains open to further changes induced by the programs. ${ }^{12}$ So it is part of the ontology of the hotel world, but keeps a prospective component because of its dependence on co-evolving programs.

This example works at two levels: the level of sociotechnical affordances, and the level of paths or trajectories of further development. The hotel key with a weight attached to it offers an affordance for it to be used in certain ways, and not in others. This is how Norman (1990) has discussed affordance designed into artefacts, e.g. doorknobs inviting the user to open the door in the right way. There is also an affordance to further develop the technology in certain directions, and not in others. For a time, increasing the weight and bulkiness of the key appeared to be the only possibility. Thus, the hotel world would be "peopled" by ever heavier keys. By now, electronic key cards offer an alternative, if the hotel manager is prepared to invest in the new locks and in other maintenance.

This links up to the second level of technological paths or trajectories. Phenomena at this level have been analysed extensively by evolutionary economists and sociologists studying technological change. In particular, Nelson and Winter (1977) introduced

\footnotetext{
11 In the recent upheaval about fraudulent human cloning work of Professor Hwang Woo-Suk of Seoul National University, the investigation (by Seoul National University) showing up the fabrications also concluded that the cloned dog was genuine (Oransky 2006).

12 Latour 1991, p. 110: "the only interesting reality is the shape of the front line". The front line between program and counter-program is also influenced by independent technological developments: key cards, first with perforations coding for the door of the room, then with a magnetic strip, relieved the burden on the hotel manager ("we can easily make a new key card") and allowed further security (change the code of the door by pressing a few keys on the hotel computer).
} 
the notion of what is now called a technological trajectory based on an emerging regime, by pointing out the strength of expectations of engineers and other technology actors about productive directions to go. "... the advent of the DC3 aircraft in the 1930's defined a particular technological regime; metal skin, low wing, piston powered planes. Engineers had some strong notions regarding the potential of this regime. For more than two decades innovation in aircraft design essentially involved better exploitation of this potential; improving the engines, enlarging the planes, making them more efficient." Thus, the airplane world was filled by ever further generations of the DC3 airplane.

Prototypes, and evolving artefacts in general, indicate what they might become. This depends just as much on how actors see, and "read" them, than on what was put into them by their immediate developers. Such "readings" are easy for mechanical contraptions like machines, motor-cars, early and present robots, but more difficult for components and materials that are invisible inputs into visible products. However, such inputs can be made "visible" in diagrams and drawings. One interesting example is a drawing with stem cells in a Petri dish in the middle and (presumably causal) arrows pointing to eventual functional applications. This diagram was featured on the USA National Institutes of Health website for a few years, and was widely reproduced, sometimes without any explanation. It had become an icon. And it shaped discussions about the potential of stem cells, for proponents as well as opponents (of the use of embryonic stem cells). ${ }^{13}$

\section{The Promise of Stem Cell Research}

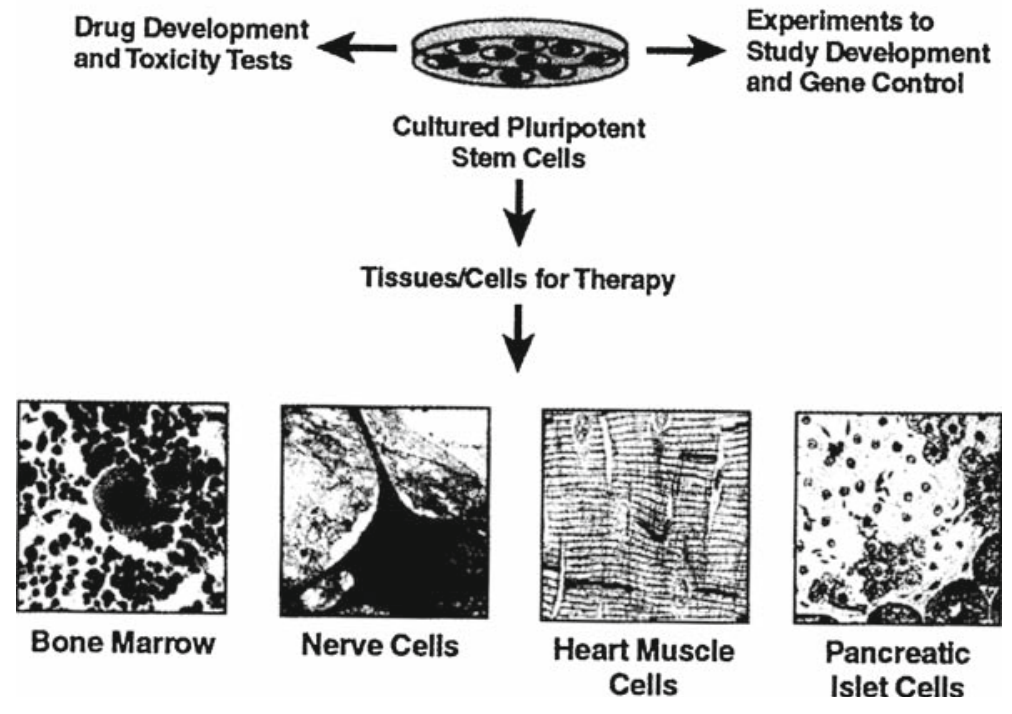

\footnotetext{
${ }^{13}$ Indicative is US Senator Frist's speech from the floor of Congress, 29 July 2005, promising support for the pending Stem Cell Research Enhancement Act. A pro-life protagonist from the beginning, now he actually followed the lines of promised applications of the diagram to outline why he was modifying his position.
} 
The possibility of "reading" embodied expectations in artefacts (up to prototypes and demos) and in/through their descriptions and diagrams implies that artefacts can be seen as generalized texts. Grint and Woolgar (1997) have pushed this view, but primarily to show how such "texts" configure the users. ${ }^{14}$ I want to pursue the ontological aspects of this view, and consider artefacts as material narratives. The notion of "material narrative" is broader than just an artefact and its embedded script. It also applies to pictures (which tell a story) and landscapes (which guide their "reader" through them).

\section{Material narratives}

Artefacts, in use or on offer, are material "stories" with routing devices [like script, cf. Akrich 1992, 1995) and affordances (Norman 1990; Hutchby 2001)] which guide the "reader" without fully determining his/her movements. Think also of "reading" a HiFi installation so that you can work with it-a competence that younger generations have acquired almost without thinking about it. Thus, "reading" of a technology is a practice, building on the affordances, rather than being dependent on conventional texts. $^{15}$

Such "readings" are not limited to the micro-interactions between artefact and user, and behind them, the designer as the "writer" of the original story. Interactions of humans with artefacts, or better, with configurations that work-if interacted with adequately_, take place in an overall sociotechnical landscape and a mosaic of sociotechnical regimes. ${ }^{16}$

Material narratives create agendas, and storylines that continue into the future. Also materially, for example when reverse salients are encountered in the expansion of (large) technical systems that can then be turned into critical problems to be addressed in further work (Hughes 1983). Hughes studied electrical power generation and networks at the turn of the 20th century. By now, there are also electricity grids, their management, and the management of (possible) failures. Our landscapes have become filled up with cables, pipelines for oil and gas, just as well as roads, and now also masts for mobile telephony, related to the "cells" covering the territory. They were

\footnotetext{
14 When Woolgar introduced the idea of technology-as-text (Woolgar 1991), he discussed various ways of understanding "reading" technology-as-text. In the interpretive (or social construction of technology) approach, the variety of possible readings is emphasized. Woolgar suggests this approach implies objective and transcendental existence of a technology, just as in labeling theory in the sociology of deviance it is a matter of different labels for a certain behaviour. His own reflexive approach is ontologically agnostic, which allows questions about how the reality of technology is created, described and sustained (Woolgar 1991, pp. 41-42). This "muddies the analytic waters", but that is exactly his purpose. But he then focuses on what this implies for the status of texts of the analysts. Similarly, Grint and Woolgar (1997) emphasize: "What happens to the structure of our [analyst's] discourse when we introduce the notion of machine as text?" (p. 70)

15 Compare also notions of material culture in anthropology, e.g. Appadurai (1986), and for a contemporary slant Miller (1998)

16 The notion of socio-technical landscape overlaps with what Appadurai (1990) called "technoscapes" and Barry (2001) "technological zones of circulation". The key point is that "landscape" is not just a passive backdrop against which humans play out their affairs. It is itself constructed, and part of the "play" is to construct parts of the backdrop.
} 
shaped by what we wanted to realize, now they shape what we can do, and how we can develop further. ${ }^{17}$

Just as gradients in a landscape (say, hills and valleys) shape the movements of people and other mobiles which traverse the landscape, a socio-technical landscape shapes action and perception. It can be seen as a material story, again with routing devices to guide the "reader" without determining its movements. Some of these routing devices have evolved naturally, and almost all of them are outcomes, at a collective level, of a variety of actor strategies, designs and interventions, and thus to some extent (and after some time) unintended by any of them. It is a dispositif, just as much as the more explicitly socio-technical dispositifs studied by Foucault and others. ${ }^{18}$

Artefacts are part of such a sociotechnical landscape, and offer avenues of access, or be like boulders that have to be circumvented. The material story is told by the overall set-up, and does not need words of human actors to unfold.

A well-known example of a sociotechnical landscape (but one which needs to be thought through further than is commonly done) are the low overpasses on Long Island, intended by their designer, New York city architect Robert Moses, to keep New York's black and poor white, who had to use busses, away from the beaches and parks he had created on Long Island (Winner 1980). ${ }^{19}$

When you have to travel on a bus, you "read" these overpasses as a barrier. Now that almost everyone has a car, the reading is different. Unless one becomes reflexive, and looks into the history to deconstruct the "naturalness" of this part of the landscape.

Is this just a matter of interpretive flexibility? No, the reader is herself part of a socio-technical ensemble including the overpasses, her having a car or not, and sociotechnical infrastructures and traditions (like being able or not to materially deconstruct an overpass). This shapes the reading. ${ }^{20}$

But such reading is interactive travelling, and modifies the material narrative. It leaves traces, like travellers wear out paths in a landscape, but sometimes also a sudden crosscut. "Reading" is also "writing". 21 This turn of phrase encapsulates the notion of prospective ontology in more foundational way than was possible in the

17 This is very clear in an interesting study of the material unification of the Netherlands (Van der Vleuten 2003).

$18 \mathrm{Cf}$. the notion of a 'sociotechnical dispositif' as introduced by Cohen et al. (2002, pp. 66, 70, 74) after Boltanski and Thevenot. Also Latour (1999, p. 192): "Purposeful action and intentionality may not be the properties of objects, but they are not properties of humans either. They are the properties of institutions, of apparatuses, of what Foucault called dispositifs." Barry (2001, p. 200) comments that "Foucault's analysis of dispositifs or apparatuses is too static to reveal the dynamic instability of socio-technical arrangements."

19 In science \& technology studies, this case has the status of an 'urban legend'. This became clear in the discussion of the complexities of the actual story of the overpasses: Joerges (1999a,b), Woolgar and Cooper (1999).

20 Here, I endogenize the observing and experiencing subject, against the dominant Cartesian tradition. This approach can be developed further in terms of narrative: the actor becomes the embedded author of an ongoing narrative, where all the characters can turn into authors/actors modifying or contending the thrust of the narrative. This is an actor-network approach, see Callon et al. (1986). Latour's analysis of programs and counter-programs can be re-formulated in these terms.

21 As Woolgar (1991, p. 37) notes for artefacts: their impact, but also their de facto shape is built during the process of design but reconstructed and deconstructed during usage. Thus (subject to the constraints of the actor-network), it is the readers who write the text of technology. 
earlier analysis of embodied expectations. Ontology cannot be other than prospective. There is always further reading/writing.

This resonates with a suggestive thought of Ortega y Gasset: "This invented lifeinvented as a novel or play is invented-man calls "human life", well-being. [...] Have we heard right? Is human life in its most human dimension a work of fiction? Is man a sort of novelist of himself who conceives the fanciful figure of a personage with its unreal occupations and then, for the sake of converting it into reality, does all the things he does-and becomes an engineer?" (Ortega y Gasset 1962, p. 108) ${ }^{22}$

Engineers, clearly, are seen as "writers". Just as in writing novels, the writer is not in complete mastery of his characters, the unfolding storyline has its own dynamics. Even when the writing is construed as putting building blocks together. Engineers (and other actors involved in creating new configurations) do not always know what they are writing. The configuration might work, but there could be surprises, directly and over time (as I intimated already in the first section).

\section{Invisible technology}

"Reading" (being routed and shaped) and "writing" (inscribing and shaping) are inseparable and constitute evolving reality, whether through experience and actions of humans as part of socio-technical assemblages, or without them. Given this overall take on a process ontology (a post-modern version of pre-Socratic ideas of the basic stuff of the world?), there still is a variety of readings/writings. Interestingly, the material narrative seems easier to read for mechanical contraptions like a motor car than for the components and materials that are invisible inputs into visible products. This is even more striking for nanotechnology, where "incredible tininess" goes together with possible (but precarious) manipulation (Nordmann 2006). At the nano-level, the "writing" is strongly mediated by instruments, and not predictable because one does not know what is happening at the nano-scale until after the fact. ${ }^{23}$ Thus, in a first round, invisibility is a matter of being hidden: the nanotechnology input in a sunscreen, or in a coating, is important for its functionality, but not visible to the user. But invisibility goes deeper, creating uncertainties about what is happening "down there", also for the "writers". This then leads on to foundational issues, for example whether our presumed technological abilities to handle invisible components are categorically different from what is labelled as magic.

\footnotetext{
22 Van Lente (1993), after whom I quote Ortega, in the final paragraph of his $\mathrm{PhD}$ thesis, turns the thought around: "The reverse is true as well: the engineers have to be like novelists. They have to write forceful fiction and make it come true as well. Actors developing technology, to paraphrase Ortega, conceive for themselves the fanciful figure of a future technology, and for the sake of converting it into reality, they, as well as others drawn into the fancy, do all the things they do. Whatever technology may be in the present, it is rooted in the future."

${ }^{23}$ An interesting example is the writing of the IBM logo with xenon atoms on a nickel surface, by Don Eigler of IBM Almaden. The picture is featured on their website, and widely copied. It appears to capture a key feature of nanotechnology, at least is read that way. Similar writings are undertaken, but they continue to be difficult: time consuming because depending on favourable circumstances out of control, like the tip of the probe becoming more pointed because some atoms have fallen off.
} 
To start with the superficial (but interesting) point: If "readers" do not see the technology inside, "writers" can develop strategies to make the technology, or at least its contribution to functionalities, visible. I already discussed the example of stem cells where diagrams and texts were used to show (and embody) causal linkages between stem cells and eventual functional applications. One simple "writer's" strategy is to announce that there is X (here, nano) inside an artefact. This is how microprocessor firm Intel created positive visibility by having a label "Intel Inside" put on laptops. However, in the case of engineered tissues, a label "Stem cells were the source" might backfire: it could incite controversy because stem cells derived from embryos continue to be controversial. In the early 1990s, labeling of GM (genetically modified) food seemed a compromise solution for the impasse, because it would shift the question of acceptability to one of consumer choice. Then, (UK) supermarkets decided against having GM food ("Frankenfood") on their shelves at all, to pre-empt possible protests-with the net effect that the compromise was undermined.

For nanotechnology, a strategy of "Nano Inside" will help people appreciate the role of nanotechnology, but may well backfire if something untoward happens elsewhere under the umbrella term "nanotechnology". Prudent companies have come to realize this, and actually shift their strategy. Cosmetics company l'Oréal used to refer to nano in its advertisements, but now speaks of "innovative molecules".

The challenge of invisibility goes further than creating visibility by labeling, i.e. making the inside visible, on the surface, to the outside. The "writing" of the material narrative is involved as well as the "reading". At the nano-scale, seeing is actually feeling (atomic force microscopy depends on a tiny tip moving up and down as it traverses a surface). Turning what is "felt" into images to be seen and read for what they might tell us, is a complicated challenge. Among themselves, nanoscientists talk of "blobbology", the craft skill of interpreting computer-generated images of surfaces. The importance of such craft skills is not exclusive to nanoscience, but nanoscience highlights the interpretative challenges involved.

The dependence of "readers" on the reporting and imaging techniques and interpretations of engineers/technologists ("writers") is further complicated by the fact that the configuring ("writing") is not fully controlled, but delegated to induced selforganisation, say, of layers of molecules on a surface. Will they actually arrange themselves in the desired way? What sort of text will they write? Because of the dominant rhetorics of control, the open-ended character of such self-organisation is backgrounded. But it may reassert itself, when the unexpected occurs.

This has definite implications at the production side, where checks and quality control are needed but can be done only after the fact, and/or where issues of liability and insurance make producers reluctant to sell such "unreliable" products. This implies that, in the end, we may actually not get many of the products that are now being promised on the basis of nanotechnology. The eventual furniture of our world will depend on the implementation of the promises, and the socio-technical constraints and limitations that are encountered.

For the ontology question, the key point is that materials and components do their work (or are expected to do so) while their agency cannot be traced, or not completely . Nordmann (2006) argues that this is a structural feature, not just a matter of something that happens to be invisible now and can be made visible if we put enough effort into it. 
That is why he introduces the notion of "noumenal technology", playing with Kant's notion of noumena and of things an sich. For Nordmann, noumenal technology is not only invisible, but out of control because outside our experience. ${ }^{24}$

Nordmann's analysis links up with a general concern, a concern about control: While technology as prospective ontology has always been with us, we may be entering a new phase, given our increased capabilities to interfere, and to a limited extent, control. This was, and is, an issue in genetic engineering, and will be highlighted further by developments in nanotechnology.

Genetic engineering adds to the furniture of the world by modifying what are thought to be the basic building blocks. Nanotechnology claims to be able, or eventually to be able, to manipulate and thus "build the world atom by atom." The rhetorics of so-called converging technologies (nano, bio, info \& cogno) suggest that all the basic building blocks (bits, atoms, neurons, genes) are in for manipulation. Thus, a continuing and pervasive vision of control which is pushed in spite of the various practical limitations that can be identified. While the promises may be empty, activities are set in motion which may lead to new findings and technological options. So there will be changes.

Nanotechnology is a domain (or patchwork of overlapping domains) where prospective ontologies materialize. There are promises about the new possibilities at the nanoscale ("there is plenty of room at the bottom" said Feynman in 1959 (see Feynman 1960) in a now often quoted dinner speech), but these are deeply ambivalent. For example, if nano-size matters (to create new properties and new effects), it also matters in terms of dangers, as with the health and environmental risks of nano-particles.

More important for my argument is the trial-and-error fiddling with matter, at the level of invisible constituents. To obtain interesting effects, self-organisation is induced-but with impredictable effects. The so-called grey-goo scenarios (where tiny nano-robots multiply and turn everything into goo) continue to draw attention, even if they are mythical. But the general concern is legitimate: technology can "escape" or "run away", cf. phrases used in the recombinant DNA and subsequent GMO debate (and also earlier, about nuclear reactors). As Jean-Pierre Dupuy has pointed out, nanoscientists and technologists embrace such ambivalencies, make them part of their job, if not of their skills. They strike out into the unknown-thus, they are intentional sorcerer's apprentices.

Here, another feature of Nordmann's attempt to capture structurally specific characteristics of technology, at least some technologies, as noumenal technology, is visible. Noumenal technology, in his view, belongs with nature outside us, with the brute and uncanny. And that is why there is concern, even fear of invisible technology-even if invisible technology can also be accepted because it delivers good things (Lianos 2003). "[P]ervasive technical interventions change the things-in-themselves, the world not as we know it but where we rely on it unknowingly." (Nordmann 2006, p. 67) "We cannot trust a noumenal technology." (Nordmann 2006, p. 71). Nordmann's and mine question then is whether such a technology can be brought out of the realm of noumena

\footnotetext{
24 Nordmann further argues that science is in the world of phenomena, and can analyse in terms of causality. Technology as actual interactions, independent of such understanding, partakes of noumena. "Technical interventions engage reality" (p. 70).
} 
into the realm of phenomena, and so become part of human experience? We may not have a choice here (if the noumenal is categorically distinct), but the question can still be raised and addressed. Particularly because there are political issues involved (in the broad sense of "political", cf. next section).

One traditional way to capture the noumenal world is through magic. Interestingly, the handling and presentation of the invisible world of nanotechnology may be similar in structure to the practices of magic. Taken in a broad sense again: practices of magic are not limited to shamanic dancing. Prescribing placebos, with demonstrable effects, is benevolent magic just as well.

A leading nanotechnology research centre, IBM Almaden (California), opens its website with the slogan "Working towards the magic of tomorrow's technology". At the bottom, there is a quote from science-fiction writer Arthur C. Clarke (his "third law"): "Any sufficiently advanced technology is indistinguishable from magic." This may be seen as playful presentation, acceptable as part of West Coast culture. But it is serious play. Compare how in the very serious German culture, one of the German nanotechnology research centres opens its website with the same quote from Clarke. Thus, there must be some resonance in the community of nano-scientists \& technologists to the notion of magic, as handling the invisible, somehow. One root may be that the handling of molecules at the nanoscale is indistinguishable from the indirect visualisations of the nanoscale: it is always inference about what is happening down there at the bottom. ${ }^{25}$

Does this imply that the philosophy of technology can (and should) be broadened to include philosophy of magic? One should be serious about magic, anyway, if (and when) it is a practice that performs, somewhat independent from the convictions that accompany it. When the Cartesian idea of control from the outside is left, a range of possibilities of modulating ongoing processes appears (of which Cartesian control is one, and an extreme, version).

Illustrative is the case of placebos that work. They confound so-called evidencebased conclusions from clinical trials, therefore attempts are made to exclude placebo effects, effectively black-boxing them. By now, there is speculation about causalities, e.g. whether placebos stimulate regenerative processes in the body, directly or through the responses of the patient. There is still too little attention to another methodological problem of clinical trials, viz. that it may well be that the drugs being tested disturb regenerative capacities. Anyway, general practitioners are willing to prescribe what they know are placebos, because of the positive effects that appear.

Invisible technologies highlight a general point. Technical interventions engage reality. Their effects are co-produced, and thus difficult to trace back to the intervention as the single source. In other words, such interventions are hopeful rather than determining. There is no categorical difference between Don Eigler struggling to create the IBM logo with xenon atoms on a nickel surface (the only evidence of its being there stemming from the instrument used to create that invisible configuration) and magic practices using other, less technically sophisticated instruments. In other words, Nordmann (2006)'s points about noumenal technology being out of

25 This is very visible (if I may say so) in the landmark paper of Hla et al. (2000) depicting induced reaction steps in graphs, images, and visualisations. 
control misses out on such practices of interaction, his view is still predicated on the Cartesian view of control. Instead, going with the flow of the noumenal allows some modulation. Cartesian control, with its projected determinism, then appears as an extreme version of modulation, and one where the principle open-ended character of modulating interventions is pushed out of sight.

\section{Political ontology}

I have articulated a monistic approach, showing the importance of overcoming dualisms, ${ }^{26}$ up to replacing ideals of Cartesian control from the outside with being embedded in processes and modulating them as one goes along, "writing" and "reading" at the same time. As in other process ontologies, there is a prospective aspect, and I emphasized this by speaking of prospective ontology, taking open-ended, unruly technology as the entrance point. My discussion of nanotechnology then offered concrete examples and further issues.

Prospective ontology includes projections (and ongoing shaping) of future states of the world as "expected", i.e. possible and possibly desirable. Thus, a prospective ontology is necessarily a political ontology. ${ }^{27}$

A first take on political ontology is ontological politics, the struggle what is to count as "real", legitmate elements of the world. An example from nanotechnology is the struggle about the realism of technological options like molecular manufacturing or nano-robots (as exemplified by the contestation about certain phrases in the USA 21st Century Nanotechnology R\&D Act of 2003). ${ }^{28}$ Formulated more generally: which human and non-human entities-in a broad sense, including configurations that work (Rip and Kemp 1998) and "ethno-epistemic assemblages" (Irwin and Michael 2003)_ are eligible, i.e. deserve, to people the world? Ontological politics is more visible in some areas, e.g. technologies for (and as) human enhancement (Miller and Wilsdon 2006), than in others. The general challenge can be expressed as: if technology is (makes) society more durable (Latour 1991), it is important to articulate the kind of durability that emerges, and perhaps modulate such processes. ${ }^{29}$

A second take on political ontology is that the politics of technology (Winner 1980) where technology is the occasion for traditional politics, have to be replaced by

\footnotetext{
26 Woolgar (2002) welcomed a "bonfire of dualities", but discussed it primarily at the level of discourse.

27 The term is used in political science to indicate that it makes a difference which entities one considers to be the basic building blocks of the political world (Hay, forthcoming). Such a use of the term 'ontology' is similar to the use in information science (note 1).

28 An amendment unanimously adopted, called for "a National Academy of Sciences study on the possible regulation of self-replicating machines, the release of such machines in natural environments, the distribution of molecular manufacturing development, the development of defensive technologies, and the use of nanotechnology to extend the capabilities of the human brain" (21st Century Nanotechnology R\&D Act of 2003, 108th US Congress, First Session, S.189, Sect. 5 b and c.) There was concern in the nano-establishment: does this indicate that Congress want the Drexler approach to be taken seriously? There was a flurry of letters and telephone calls, including imputations of political wheeling and dealing. Then it died.

29 Later, Latour continues this shift away from "the interminable quarrel over the foundations of the universe" to questions how humans and non-humans "compose the raw material of the collective" (Latour (2004, p. 61).
} 
ontological politics (in a broad sense) where technology is the topic. For example, Beck's notion of sub-politics can be extended to the de facto sub-politics of artefacts, as these settle debates, implicitly or explicitly. Of course, it is not the artefact per se which settles a debate. Artefacts are knots \& seams in evolving and irreversibilising so-called seamless webs (Hughes 1986; Rip and Kemp 1998). It is the overall process that counts, in which artefacts can be more or less visible.

In a third take on political ontology, the issue of control returns. If we cannot control for our interference, in general because of unruliness and open-endedness, and for nanotechnology, in spite of its projections of control, because it is based on impredictable manipulations of invisible building blocks, lots of things still happen, but without clear accountabilities. The post-phenomenological analysis of Verbeek $(2005,2006)$ importantly adds to this by highlighting the role of human-technology associations, which include "technological intentionalities". In more traditional terms: Who is accountable if control is delegated to self-organized matter? Nanotechnology is perhaps an extreme case, but technology was always unruly and unfinished.

The ideology of control, however, as part of technical rationality, has been accepted by many commentators, and this has created intellectual and sometimes political debate about technology which is actually beside the point ${ }^{30}$ Or at least backgrounds and eclipses a much more important point which I have tried to bring out by drawing attention to prospective ontology and unruly technology. "Technological intentionalities" must be part of the conversation, and ongoing repair work is more important than a master plan (or a master configuration that works), which should cater for all eventualities. ${ }^{31}$

I have come a long way since I started looking at the "furniture of the world". I was addressing engineers then, the mandated "writers" of material narratives. My analysis has broadened this picture. Everybody, and everything, is involved. Political ontology is integral to prospective ontology. Prospective ontology opens up the traditional idea of ontology as what is somehow given. So if not given, it might be influenced, modulated. My notion of material narratives, and ongoing "reading" plus "writing", indicates that modulation occurs all the time. Highlighting the aspect of political ontology implies that the de facto politics become visible, and more reflexive approaches become possible.

Open Access This article is distributed under the terms of the Creative Commons Attribution Noncommercial License which permits any noncommercial use, distribution, and reproduction in any medium, provided the original author(s) and source are credited.

\footnotetext{
30 In a way, technology is victim of the rationalizing tendencies of modernity.

31 Interestingly, recent discussions about governance have undermined the idea of rational control. If it ever worked, it was because of repair work at lower levels in the system. This then implies that some suggestions for productive governance can also be applicable to technology, like the focus on 'spaces' where things can happen, and actors can negotiate. From my analysis of prospective ontology, 'times' must be added: governance includes repair of the future.
} 


\section{References}

Akrich, M. (1992). The de-scription of technical objects. In W. Bijker \& J. Law (Eds.), Shaping technology/building society (pp. 205-223). Cambridge, Mass: MIT Press.

Akrich, M. (1995). User representations: Practices, methods and sociology. In A. Rip, T. J. Misa \& J.W. Schot, (Eds.), Managing technology in society. The approach of constructive technology assessment (pp. 167-184). London: Pinter Publishers St. Martin's Press.

Appadurai, A. (Ed.). (1986). The social life of things. Commodities in cultural perspective. Cambridge: Cambridge University Press.

Appadurai, A. (1990). Disjuncture and difference in the global cultural economy. Theory, Culture \& Society, 7(2-3), 295-310. doi:10.1177/026327690007002017.

Baird, D., Nordmann, A., \& Schummer, J. (Eds.). (2004). Discovering the nanoscale. Amsterdam: IOS Press.

Barry, A. (2001). Political machines. Governing a technological society. London: The Athlone Press.

Bensaude-Vincent, B. (2006). Two cultures of nanotechnology? In J. Schummer \& D. Baird (Eds.), Nanotechnology challenges (pp. 7-28). Singapore: World Scientific Publishing Co.

Bergson, H. (1911/1983). Creative evolution (A. Mitchell, Trans.). Lanham: University Press of America.

Bijker, W.E., \& Law, J. (Eds.). (1992). Shaping technology/building society. Studies in sociotechnical change. Cambridge: The MIT Press.

Callon, M., Law, J., \& Rip, A. (1986). Mapping the dynamics of science and technology. Basingstoke and London: Macmillan.

Callon, M. (1999). Whose imposture? physicists at war with the third person. Social Studies of Science, 29, 261-286.

Cohen, C., Walsh, V., \& Richards, A. (2002). Learning by designer-user interaction: An analysis of usability activities as coordination mechanisms in the product development process. In C. E. Garcia \& L. SanzMenendez (Eds.), Management and Technology (Vol. 5, pp. 61-78). Brussels: European Commission, Directorate-General Science, Research and Development, 1998. COST A3.

De Laat, B. Scripts for the future. Technology foresight, strategic evaluation and socio-technical networks: the confrontation of script-based scenarios. PhD Thesis, University of Amsterdam, 18 December 1996.

De Laat, B. (2000). Future scripts. In N. Brown, B. Rappert \& A. Webster (Eds.), Contested futures. A sociology of prospective techno-science. Aldershot: Ashgate.

Dupuy, J.-P., \& Grinbaum, A. (2006). Living with uncertainty: Toward the ongoing normative assessment of nanotechnology. In J. Schummer \& D. Baird (Eds.), Nanotechnology challenges (pp. 287-314). Singapore: World Scientific Publishing Co.

Feynman, R. (1960). There's plenty of room at the bottom. Engineering and Science, 23, 22-36.

Grint, K., \& Woolgar, S. (1997). The machine at work: Technology, work and organization, Cambridge: Polity Press.

Hay, C. (forthcoming). Political ontology. In R. E. Goodin \& C. Tilly (Eds.), The oxford handbook of contextual political analysis.

Heidegger, M. (1977). The question concerning technology, and other essays. New York: Harper and Row.

Hla, S.-H., Bartels, L., Meyer, G., \& Rieder, K.-H. (2000). Inducing all steps of a chemical reaction with the scanning tunneling microscope tip: Towards single molecule engineering. Physical Review Letters, 85(13), 2777-2780. doi:10.1103/PhysRevLett.85.2777.

Hughes, T.P. (1983). Networks of power. Electrification in western society 1880-1930. Baltimore, MD: Johns Hopkins University Press.

Hughes, T.P. (1986). The seamless web: technology, science, etcetera, etcetera. Social Studies of Science, 16, 281-292. doi:10.1177/0306312786016002004.

Hutchby, I. (2001). Technologies, texts and affordances. Sociology, 35, 441-456.

Irwin, A., \& Michael, M. (2003). Science, social theory and public knowledge. Maidenhead and Philadelphia: Open University Press.

IWGN (Interagency Working Group on Nanoscience.Engineering and Technology). (1999). Nanotechnology-shaping the world atom by atom. Washington: National Science and Technology Council.

Joerges, B. (1999a). Do politics have artefacts? Social Studies of Science, 29(3), 411-431. doi:10.1177/ 030631299029003004.

Joerges, B. (1999b). Scams cannot be busted. Reply to Woolgar and Cooper. Social Studies of Science, 29(3), 450-457. doi:10.1177/030631299029003006. 
Latour, B. (1991). Technology is society made durable. In J. Law (Ed.), A sociology of monsters: Essays on power, technology and domination (pp. 103-131). London : Routledge.

Latour, B. (1999). Pandora's hope. Essays on the reality of science studies. Cambridge: Harvard University Press.

Latour, B. (2004). Politics of nature. How to bring the sciences into democracy. Cambridge: Harvard University Press.

Lianos, M. (2003). Social control after Foucault. Surveillance \& Society, 1(3), 412-430.

Lombardi, O., \& Labarca, M. (2005). The ontological autonomy of the chemical world. Foundations of Chemistry, 7, 125-148. doi:10.1007/s10698-004-0980-6.

Miller, D. (Ed.). (1998). Material cultures. Why some things matter. Chicago: University of Chicago Press.

Miller, P., \& Wilsdon, J. (Eds.). (2006). Better humans? The politics of human enhancement and life extension. London: DEMOS.

Mokyr, J. (1990). The lever of riches. New York: Oxford University Press.

Mol, A. (1999). Ontological politics: A word and some questions. In J. Law \& J. Hassard (Eds.), Actornetwork theory and after (pp. 74-89). Oxford: Blackwell's.

Nelson, R.R., \& Winter, S.G. (1977). In search of a useful theory of innovation. Research Policy, 6, 47-76. doi:10.1016/0048-7333(77)90029-4.

Nersessian, N.J. (2006). The cognitive-cultural systems of the research laboratory. Organization Studies, 27(1), 125-145. doi:10.1177/0170840606061842.

Nordmann, A. (2006), Noumenal technology: Reflections on the incredible tininess of nano. In J. Schummer \& D. Baird (Eds.), Nanotechnology Challenges (pp. 49-72). Singapore: World Scientific Publishing Co.

Norman, D.A. (1990). The design of everyday things. New York: Doubleday.

Oransky, I. (2006), All Hwang human cloning work fraudulent, The Scientist, published 10 January 2006 on the website http://www.the-scientist.com.

Ortega y Gasset, J. (1962). Man the technician, In History as a system and other essays toward a philosophy of history (pp. 87-164). New York: Norton (Originally published in 1940).

Rip, A. (2000). There's no turn like the empirical turn. In P. Kroes \& A. Meijers (Eds.), The empirical turn in the philosophy of technology (pp. 3-17). Amsterdam: JAI, an imprint of Elsevier Science.

Rip, A. (2006). A co-evolutionary approach to reflexive governance-and its ironies. In J.-P. Voß, D. Bauknecht \& R. Kemp (Eds.), Reflexive governance for sustainable development (pp. 82-100). Cheltenham, UK: Edward Elgar.

Rip, A., \& Kemp, R. (1998). Technological change. In S. Rayner \& E.L. Malone (Eds.), Human choice and climate change, Vol. 2, Ch. 6, pp. 327-399. Columbus: Battelle Press.

Schön, D. (1983). The reflective practitioner. How professionals think in action. New York: Basic Books.

Schummer, J., \& Baird, D. (Eds.). (2006). Nanotechnology challenges. Implications for philosophy, ethics and society. Singapore: World Scientific Publishing Co.

Stein, R. L. (2004). Towards a process philosophy of chemistry. Hyle-International Journal for Philosophy of Chemistry, 10 (1), 1-17.

Stoelhorst, J.-W. (1997). In search of a dynamic theory of the Firm. An evolutionary perspective on competition under conditions of technological change, with an application to the semi-conductor industry. University of Twente, 03-12-1997.

Tsoukas, H. (2005). Complex knowledge: Studies in organizational epistemology. Oxford: Oxford University Press.

Van den Belt, H., \& A. Rip. (1987). The Nelson-Winter/Dosi model and synthetic dye chemistry. In W. E. Bijker, T. P. Hughes \& T. J. Pinch (Eds.), The social construction of technological systems. New directions in the sociology and history of technology (pp. 135-158). Cambridge: MIT Press.

Van der Vleuten, E.B.A. (2003). De materiële eenwording van Nederland. In J.W. Schot, H.W. Lintsen, A. Rip \& A.A. Albert de la Bruhèze (Eds.), Techniek in Nederland in de Twintigste Eeuw. VII. Techniek en Modernisering. Balans van de Twintigste Eeuw (pp. 43-73). Zuthphen: Walburg Pers.

Van de Ven, A. H., \& M. S. Poole. (2005). Alternative approaches for studying organizational change. Organization Studies, 26(5), 1377-1404. doi:10.1177/0170840605056907.

Van Lente, H. (1993). Promising technology-the dynamics of expectations in technological developments, $\mathrm{PhD}$ Thesis. Enschede: University of Twente.

Van Lente, H., \& A. Rip. (1998). Expectations in technological developments: An example of prospective structures to be filled in by agency, In C. Disco \& B.J.R. van der Meulen (Eds.), Getting New Technologies Together (pp. 195-220). Berlin: Walter de Gruyter. 
Verbeek, P.-P. (2005), What things do. Philosophcal reflections on technology, agency, and design. University Park: Pennsylvania State University Press.

Verbeek, P.-P. (2006). Materializing Morality-design ethics and technological mediation. Science, Technology \& Human Values, 31(3), 361-380. doi:10.1177/0162243905285847.

Whitehead, A.N. (1929). Process and reality. London: Macmillan.

Winner, L. (1980). Do artifacts have politics? reprinted in D. MacKenzie \& J. Wajcman (eds.), The social shaping of technology (Second Edition), pp. 28-40. Buckingham \& Philadelphia: Open University Press.

Wood, M. (2002). Mind the gap? A processual reconsideration of organizational knowledge. Organization, 9(1), 151-171. doi:10.1177/1350508402009001354.

Woolgar, S. (1991). The turn to technology in social studies of science. Science, Technology \& Human Values, 16(1), 20-50. doi:10.1177/016224399101600102.

Woolgar, S., \& Cooper, G. (1999). Do artefacts have ambivalence? Moses' Bridges, Winner's Bridges and other urban legends in S\&TS. Social Studies of Science, 29(3), 433-449. doi:10.1177/ 030631299029003005.

Woolgar, S. (2002). After word?-on some dynamics of duality interrogation. Or: Why bonfires are not enough. Theory, Culture \& Society, 19(5-6), 261-270. doi:10.1177/026327602761899255.

Wynne, B. (1988). Unruly technology: practical rules, impractical discourses and public understanding. Social Studies of Science, 18, 147-167. doi:10.1177/030631288018001006. 